Abbreviated Key Title: Sch J Econ Bus Manag

ISSN 2348-8875 (Print) | ISSN 2348-5302 (Online)

Journal homepage: https://saspublishers.com/sjebm/

\title{
A Study on Lateral Effect upon Regional Economy Caused by Consumption of China's A-Class Tourist Attractions
}

\author{
Yang $\mathrm{Yi}^{*}$
}

School of Management, Jinan University, Guangzhou, China

DOI: $10.36347 /$ sjebm.2020.v07i02.001

| Received: 01.02.2020 | Accepted: 08.02.2020 | Published: 14.02.2020

*Corresponding author: Yang Yi

Abstract

Original Research Article

Lateral-effect refers to the increase of one kind of consumer goods (or investment/export), which may lead to the increase of another kind of consumer goods (or investment/export). For example, ticket consumption in scenic spots can lead to the consumption of accommodation and catering [1]. The study of the lateral-effect is a new topic in the study of industrial correlation in recent years. The study of the lateral-effect of ticket consumption in scenic spots on regional economy is helpful to grasp the focus of the industrial layout of tourist destinations. Based on the related research results of predecessors, this paper takes the a-level scenic spots of national natural landscape in China as an example, applies the input-output method, introduces the theory of lateral-effect, and calculates the lateral-effect multiplier of ticket consumption of scenic spots on regional economy. The calculation results show that for every unit of added value created by scenic spot tickets, 6.74 units of added value of other sectors of the national economy can be driven by the lateral-effect, indicating that a-level scenic spots of national natural landscape in China have a significant driving effect on regional economy. Through calculation and analysis, this paper draws the conclusion that the scenic spot should gradually cut ticket prices, spend more resources on improving tourists' consumption of shopping, catering and accommodation, and optimize the structure of tourists' consumption.

Keywords: Scenic spot consumption; lateral effect; Input and output.

Copyright @ 2020: This is an open-access article distributed under the terms of the Creative Commons Attribution license which permits unrestricted use, distribution, and reproduction in any medium for non-commercial use (NonCommercial, or CC-BY-NC) provided the original author and source are credited.

\section{THE INTRODUCTION}

With the stable development of social economy, China has entered the stage of mass tourism, and the total consumption of tourism is increasing, thus promoting the continuous improvement of the industrial status of tourism industry. The 12th five-year plan for service industry development issued by China's State Council, a coordinating body often likened to the United States president's cabinet, in 2012 has identified tourism as a strategic pillar industry of the national economy. Promulgated by the China national tourism administration in 2017, China's tourism scenic area development report pointed out that in 2017, the constituents of the domestic tourists traveling consumption of food and beverage cost accounted $27.5 \%$, transport costs accounted for $12.2 \%$, scenic spot ticket consumption accounted for $22.6 \%$, shopping cost $23.3 \%$, accommodation costs accounted for $8.0 \%$, cultural entertainment spending accounts for 5.6\%, other $0.7 \%$, scenic spot ticket sales still occupy a large proportion. On the one hand, this reflects the high dependence of local economy on ticket revenue, on the other hand, it also shows that the development of China's tourism is still in an immature stage.
In fact, if analyzed from a macro perspective, it can be found that the economic contribution of other consumption caused by tourists in ticket consumption is far greater than the contribution of scenic spot ticket consumption itself. This shows that ticket consumption in scenic spots has a huge multiplier effect, and local governments should pay more attention to the comprehensive income of the whole region instead of ticket revenue when setting ticket prices. By using the input-output table of China in 2012, based on the inputoutput theory and tourism multiplier theory, this paper calculate the lateral effect multiplier of scenic spot tickets consumption to the consumption of tourism destination, aiming to analysis the comprehensive economic effects in tourist destination caused by the tickets consumption. And provide scientific and reasonable basis for the setting of the scenic spot ticket prices and related policy and regional tourism development planning.

\section{LITERATURE REVIEW}

The concept of lateral effect is first put forward by Rostow in his book economics from takeoff to sustainable growth. It refers to the increase of one kind of consumer goods (or investment / export), which 
may lead to the increase of another kind of consumer goods (or investment / export). For example, the consumption of scenic spot tickets can lead to the consumption of accommodation and catering [1].

Lateral effect is a new topic in the study of tourism multiplier, but at present, there are few related research results, and most of them are qualitative descriptions. Only a few studies have tried to quantify the lateral effect. Xiaozhen Chen [2] divides lateral effects into competitive and collaborative ones, and tries to build a lateral association network model to provide a basis for the quantification of lateral effects; Yi Liu [1] takes Danxia Mountain, the world heritage site, as an example, makes a quantitative analysis of the lateral effects of scenic spot consumption for the first time, and its constructed structure tree model of scenic spot consumption multiplier effect describes the ticket consumption of scenic spots. The diffusion path of regional economic impact, in which the lateral effect has an impact on the tourism economy of the destination from the exogenous path, is divided into direct lateral effect and indirect lateral effect.

Previous studies on tourism multiplier laid a solid foundation for the study of lateral effects. Keynesian multiplier model and Leontief input-output model are both research models of modern tourism multiplier theory. However, the marginal consumption tendency of Keynesian multiplier model is difficult to measure in reality, and the input-output model is easier to calculate, so the research on tourism multiplier in academia is basically derived from the input-output model. At present, a few researches on the measurement of lateral effect multiplier [1] are also based on the basic theory of input-output multiplier.

At present, there is no special work on the lateral effect in countries except China. The research on the tourism multiplier effect started in the 1970s, and the research object is mainly in the hotel industry. In the 1990s, the paper mainly studied the industrial association and the tourism income multiplier and economic multiplier effect of related areas from the perspective of input-output analysis, such as [3, 4]. Since the 21 st century, there has been a new expansion in research methods. In addition to further using the input-output table to study the relevant characteristics of an industry [5-7], new models and methods such as CGE model, Sam multiplier analysis, VAR model have also been introduced [8-12].

Different from the current study of tourism multiplier as government service in China, western developed countries adopt market economy mechanism, and the government basically takes a non intervention attitude towards the development of tourism. Therefore, in the research results of tourism multiplier, it is basically based on accommodation and catering industry or tourism destination as the research object, and there are still research literature on multiplier effect of public tourism resources scenic spots.

China's domestic research on tourism multiplier is mainly based on the input-output theory, focusing on the internal relations between industrial sectors [13-20].

Liu Qiyun [21] pointed out that there are some problems in the analysis of input-output multiplier at present, either exaggerating the multiplier effect, forming a false economic prosperity, or underestimating the multiplier effect, omitting some factors that should be considered, thus there existing larger errors in the model calculation. In order to answer the abovementioned real economic problems comprehensively and correctly, we must start with the basic principle of input-output multiplier, clarify the transmission mechanism of the effect of input-output multiplier, and take the lateral effects among the final products into account. After that, a few literature have discussed the lateral effect multiplier of a single case, but they have not formed a conclusion of universal significance, which needs to be expanded in research breadth. Based on this, this paper uses the theory of input-output multiplier to measure the lateral effect multiplier of national natural landscape class a scenic spots on regional economy, and analyzes the comprehensive contribution of ticket consumption of scenic spots to regional economy, aiming to broaden the depth and breadth of lateral effect multiplier research and enrich the research results in the field of tourism multiplier.

\section{Model Construction and Research Design Model Construction}

Liu Yi [1] in the study of the comprehensive multiplier effect of the consumption of Danxia Mountain, a world natural heritage scenic spot, constructed the structure tree model of the consumption multiplier effect of scenic spot, and used the model to calculate the comprehensive multiplier effect of the consumption of scenic spot tickets including the lateral effect multiplier. Based on this model, this paper studies the lateral effect multiplier of A-level scenic spots in China. According to this model, the lateral effect of ticket consumption in scenic spots studied in this paper mainly affects the economy of tourist destinations through exogenous paths. As shown in Figure-1, the ticket consumption of the scenic spot will lead to a series of consumption, such as transportation, catering, accommodation, etc., which will have a certain impact on the economy of the tourist destination. The path of the impact of ticket consumption on the destination economy includes the endogenous path and the exogenous path. Through the endogenous path, i.e. the internal relationship between the industrial sectors, it shows the industrial spread effect of the ticket consumption through the industrial association. Through the exogenous path, i.e. the external relationship between the tourism consumption, it shows 
the lateral effect caused by the ticket consumption. In the exogenous path, the related consumption caused by the ticket consumption of scenic spots shows the direct lateral effect, and the change of national economic output caused by the consumption of relevant departments through the industrial ripple effect shows the indirect lateral effect. Combined with the characteristics of tourism, the lateral effect can better reflect the characteristics of the impact of tourism on regional economy than the ripple effect.

In this paper, the consumption multiplier structure tree model of scenic spots is used. First, the direct lateral effect multiplier and indirect lateral effect multiplier of scenic spot ticket consumption are calculated from the exogenous path, and then the ripple effect multiplier is calculated from the endogenous path. By comparing the two, the influence degree and characteristics of lateral effect of scenic spot ticket consumption on regional economy are revealed. At the same time, by comparing the sector structure of the lateral effect with the multiplier of the added value of the tourism output of the relevant departments, this paper reveals the characteristics and laws of the lateral effect of the ticket consumption of the natural landscape type a scenic spot on the regional economy, and clarifies the development direction for the optimization of the tourist consumption structure.

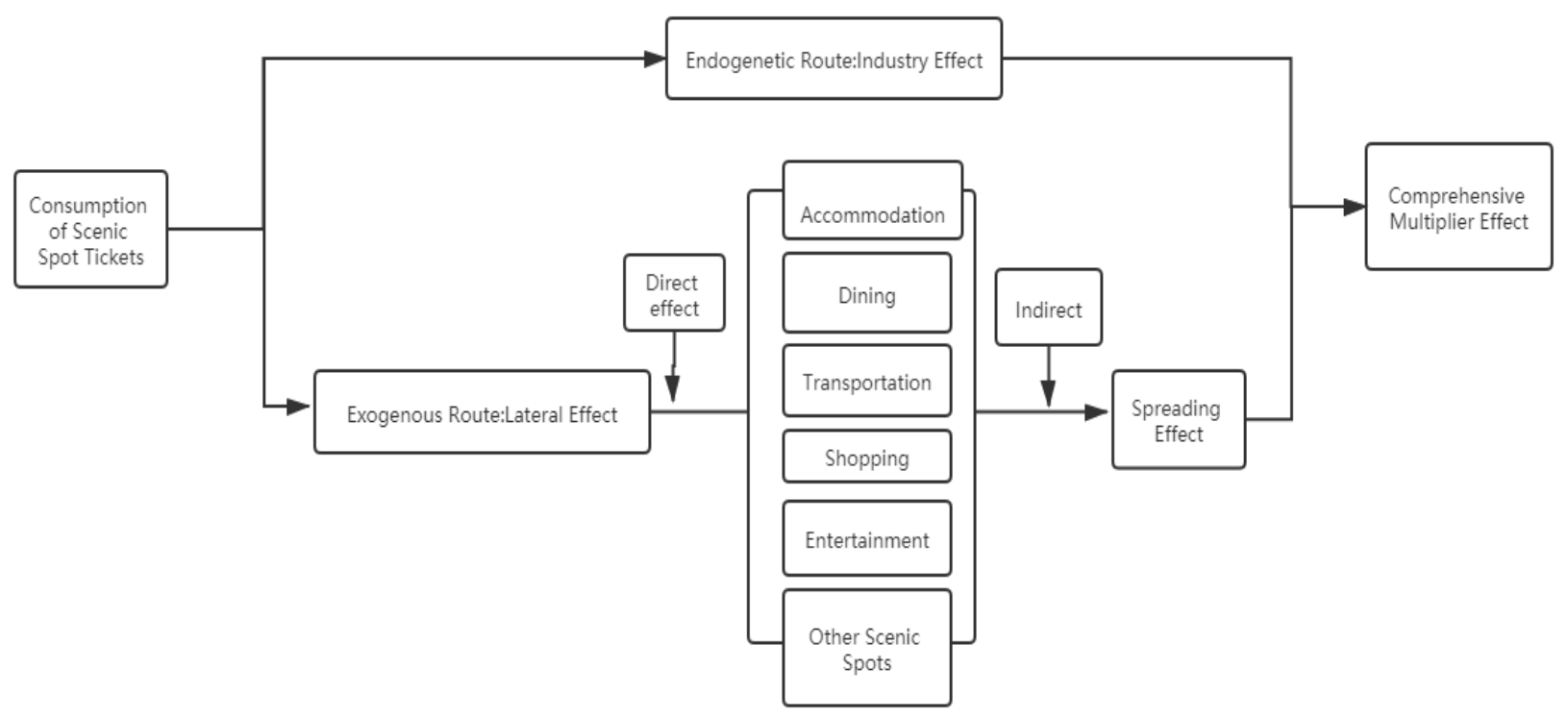

Fig-1: The structure tree model of the comprehensive multiplier effect in scenic spots

\section{RESEARCH DESIGN \\ Research Object}

This paper chooses the natural landscape scenic spots in the national A-level scenic spots as the calculation object. First, considering that the natural landscape scenic spots are generally located in rural and remote areas and have typical tourism attraction properties, it can eliminate the interference of nontourism factors on the related tourism consumption to the maximum extent, and the conclusion can provide more valuable reference for choosing the tourism development mode in the resource-based tourism destination.

Second, the natural scenic spot has a large area, many supporting service facilities and more related tourism consumption. According to the 2015 China tourism scenic spot development report, issued by China National Tourism Administration, the natural scenic spot has the highest income of 124.015 billion yuan in every type of scenic spots, accounting for $35.65 \%$ of the total income. Besides, the lateral effect of natural scenic spots is more significant than other types of scenic spots.

\section{RESEARCH METHODS}

Based on the input-output analysis method and the consumption multiplier structure tree model constructed by Liu Yi and others, this paper calculates the lateral effect multiplier of scenic spot ticket consumption through exogenous path, reveals the size and structure of lateral effect by comparing the lateral effect with scenic spot ticket consumption wave and effect multiplier, and reveals the size and structure of lateral effect by comparing the lateral effect multiplier of scenic spot ticket consumption with the ripple effect of it. Moreover, this paper compare the lateral effect multiplier of scenic spot ticket consumption with multiplier of added value of tourism output of all sectors to provide the direction for the optimization of the lateral effect structure. In order to reflect directly and truly reflect the multiplier effect of each department on the local economy, this paper uses the added value as the measurement index. 


\section{Data Source and Description}

The consumption structure data of China national natural landscape type A-scenic spot tourists used in this study comes from the 2015 China tourism development report, prepared by China National Tourism Administration. The consumption structure of China national natural landscape type a scenic spot obtained is shown in Table-1. The basic flow table of 139 departments used to calculate input-output is from China national input-output table of 2012. The coefficient matrix and the corresponding Leontief inverse matrix of the reduction model are calculated by MATLAB software.

Table-1: The consumption structure of national natural landscape type A-class tourist attractions

\begin{tabular}{|c|c|c|c|c|c|c|c|c|}
\hline $\begin{array}{l}\text { Total amount consumption } \\
\text { and proportion }\end{array}$ & Ticket & Commodity & Catering & $\begin{array}{c}\text { Transpor } \\
\text {-tation }\end{array}$ & $\begin{array}{c}\text { Accommo } \\
\text {-dation }\end{array}$ & $\begin{array}{c}\text { Enterta } \\
\text {-inment }\end{array}$ & 0thers & Total \\
\hline Total amount (billion/RMB ) & 329.01 & 183.29 & 280.89 & 161.71 & 251.5 & 21.33 & 12.4 & 1240.15 \\
\hline Proportion & $26.53 \%$ & $14.78 \%$ & $22.65 \%$ & $13.04 \%$ & $20.28 \%$ & $1.72 \%$ & $1.00 \%$ & $100 \%$ \\
\hline
\end{tabular}

Source: compiled from the report on the development of China's tourist attractions in 2015

\section{DATA ANALYSIS}

\section{Analysis of Lateral Effect Multiplier of Ticket Consumption in Scenic Spots \\ Analysis of Direct Lateral Effect Multiplier}

The direct lateral effect of scenic spot ticket consumption is the consumption of accommodation, catering and other departments directly caused by scenic spot ticket consumption through exogenous path. Before measuring the direct lateral effect multiplier of ticket consumption in scenic spots, it is necessary to sort out the tourist consumption items and their industrial departments.

Since the data of transportation consumption in the report is directly reported by each scenic spot to the relevant statistical department, each scenic spot can't get the statistic of visitors' consumption of long-distance transportation such as trains, long-distance buses, airplanes, etc., and the statistic is about mainly the battery cars and scenic spot sightseeing cars required by the scenic spot's traffic transportation. Therefore, the transportation consumption in this study correspond to the road transport sector in national economic sector.

According to the classification of corresponding departments for commodity consumption projects, the consumption composition of tourists should be considered. Referring to the field survey on the consumption of tourists in Danxia Mountain, it can be seen that the consumption of tourists in national natural landscape class a scenic spot mainly includes the purchase of local specialties, souvenirs and other commodities. Corresponding to the national inputoutput table of 139 departments in 2012, it mainly involves agricultural products, vegetables Fruit, nuts and other agricultural and sideline products processing products, cultural and educational, industrial and aesthetic, sports and entertainment products, as well as wholesale and retail four departments, for the convenience of calculation, unified into a new Department: tourism commodities department. The rest of catering, accommodation, entertainment and other consumption have corresponding departments in the input-output table, so 139 departments in the inputoutput table are reorganized into a new input-output table of 136 departments. See Table-2 for the classification and arrangement of tourist consumption projects and industrial departments of national natural landscape class a scenic spots. For the corresponding department classification of commodity consumption items, it is necessary to consider the consumption composition of tourists. With reference to the field survey of tourists 'consumption in Danxia Mountain, it can be seen that the shopping consumption of tourists in the national natural landscape type A scenic spots mainly includes the purchase of local souvenirs, tourist souvenirs and other commodities Corresponding to the 2012 input-output table of 139 departments across the country, it mainly involves agricultural products, vegetables, fruits, nuts, and other processed agricultural and sideline products, cultural and educational, industrial beauty, sports and entertainment supplies, and wholesale and retail four departments. Convenient and unified under a new department: tourism commodities department. The rest of the catering, accommodation, entertainment, and other consumption have corresponding departments in the input-output table, so the 139 departments in the input-output table are reorganized into a new input-output table of 136 departments. The classification and arrangement of tourist consumption items and their industrial sectors of the national natural landscape-type A-level scenic spots are shown in Table-2. 
Table-2: Matching the consumption of national natural landscape type A-class tourist attractions with industries

\begin{tabular}{|c|c|c|}
\hline $\begin{array}{l}\text { Consumer } \\
\text { items }\end{array}$ & \multicolumn{2}{|l|}{ Corresponding department } \\
\hline Ticket & Public facilities management & \\
\hline \multirow[t]{4}{*}{ Commodity } & Agricultural products & \multirow{4}{*}{$\begin{array}{l}\text { Tourism commodities } \\
\text { department }\end{array}$} \\
\hline & $\begin{array}{l}\text { Vegetables, fruits, nuts, and other processed agricultural and sideline } \\
\text { products }\end{array}$ & \\
\hline & $\begin{array}{l}\text { Cultural and educational, industrial beauty, sports and entertainment } \\
\text { supplies }\end{array}$ & \\
\hline & Wholesale and retail & \\
\hline Transportation & \multicolumn{2}{|l|}{ Road transport } \\
\hline Catering & \multicolumn{2}{|l|}{ Catering } \\
\hline Accommodation & \multicolumn{2}{|l|}{ Accommodation } \\
\hline Entertainment & \multicolumn{2}{|l|}{ Entertainment } \\
\hline Others & \multicolumn{2}{|l|}{ Others } \\
\hline
\end{tabular}

According to the data on the composition of tourist consumption of national natural landscape type A scenic spots provided in the "2015 China Tourism Scenic Area Development Report", and the national natural landscape in 2015 was calculated according to the added-value rate of each department in the 2012 national input-output table and corresponding added value of Type A scenic spots. Table-3 shows the precise data.

Table-3: Consumption related data of national natural landscape type A-class tourist attractions

\begin{tabular}{|c|c|c|c|c|c|}
\hline $\begin{array}{l}\text { Consumer } \\
\text { items }\end{array}$ & \multicolumn{2}{|l|}{ Corresponding department } & $\begin{array}{l}\text { Total } \\
\text { consumption unit } \\
\text { (Billion /RMB) }\end{array}$ & $\begin{array}{l}\text { added- } \\
\text { value } \\
\text { rate }\end{array}$ & $\begin{array}{l}\text { Total added } \\
\text { value }(100 \\
\text { million/RMB }) \\
\end{array}$ \\
\hline Tickets & \multicolumn{2}{|l|}{ Public facilities management } & 329.0 & 0.41 & 135.10 \\
\hline \multirow[t]{4}{*}{ Commodity } & Agricultural products & \multirow{4}{*}{$\begin{array}{l}\text { Tourism } \\
\text { commodities } \\
\text { department }\end{array}$} & \multirow[t]{4}{*}{183.3} & \multirow[t]{4}{*}{0.61} & \multirow[t]{4}{*}{111.48} \\
\hline & $\begin{array}{l}\text { Vegetables, fruits, nuts, and } \\
\text { other processed agricultural } \\
\text { and sideline products }\end{array}$ & & & & \\
\hline & $\begin{array}{l}\text { Cultural and educational, } \\
\text { industrial beauty, sports and } \\
\text { entertainment supplies }\end{array}$ & & & & \\
\hline & Wholesale and retail & & & & \\
\hline Transportation & \multicolumn{2}{|l|}{ Road transport } & 161.7 & 0.40 & 64.96 \\
\hline Catering & \multicolumn{2}{|l|}{ Catering } & 280.9 & 0.40 & 113.73 \\
\hline Accommodation & \multicolumn{2}{|l|}{ Accommodation } & 251.5 & 0.42 & 106.44 \\
\hline Entertainment & \multicolumn{2}{|l|}{ Entertainment } & 21.3 & 0.55 & 11.62 \\
\hline Others & \multicolumn{2}{|l|}{ Others } & 12.4 & 0.46 & 5.68 \\
\hline
\end{tabular}

Tourism activities are comprehensive. Tourists spend their tickets at tourist destinations along with shopping and transportation. For the national natural landscape-type A-level scenic spots, in addition to the consumption of scenic tickets, tourists consume the most in the catering and accommodation industries. After the specific driving data of scenic area ticket consumption added value to other sectors' consumption added value is obtained, according to the definition of direct lateral effect multiplier, the direct lateral effect multiplier of scenic area ticket consumption added value to each sector consumption added value can be calculated. The calculation formula for the direct lateral effect multiplier of each department is as follows:

$$
D L K_{j}=\Delta I_{j} \div \Delta I_{\text {ticket }}
$$

Among them, $\mathrm{DLK}_{\mathrm{j}}$ is the direct lateral effect multiplier of department $\mathrm{j}, \Delta \mathrm{Ij}$ is the corresponding added value of tourist consumption of department $j$, and
$\Delta \mathrm{I}$ is the corresponding added value of ticket consumption of scenic spots. The comprehensive direct lateral effect multiplier of the scenic area is the sum of the direct lateral effect multipliers of each department. The calculation formula is as follows:

$$
D L K=\sum_{j=1}^{n} \Delta I_{j} \div \Delta I_{\text {ticket }} \ldots \ldots \ldots \ldots
$$

Among them, DLK is the comprehensive direct lateral effect multiplier of scenic spot consumption, $\Delta \mathrm{Ij}$ is the corresponding added value of tourist consumption of department $\mathrm{j}$, and $\Delta \mathrm{I}$ ticket is the corresponding added value of ticket consumption of scenic spots. According to formulas (1) and (2), the direct lateral effect multiplier and the comprehensive direct lateral effect multiplier for each department's ticket consumption in the scenic area are calculated. The results are shown in Table- 4 . 
Table-4: Direct lateral effect multiplier caused by national natural landscape type A-class tourist attractions ticket consumption

\begin{tabular}{|l|l|l|}
\hline Consumer items & Corresponding department & direct lateral effect multiplier of department \\
\hline Commodity & Tourism commodities department & 0.83 \\
\hline Transportation & Road transport & 0.48 \\
\hline Catering & Catering & 0.84 \\
\hline Accommodation & Accommodation & 0.79 \\
\hline Entertainment & Entertainment & 0.09 \\
\hline Others & Others & 0.04 \\
\hline comprehensive direct lateral effect multiplier & 3.06 \\
\hline
\end{tabular}

From the data in the table, it can be seen that the direct lateral effect multiplier of the consumption of natural landscape type A scenic spots on the catering, commodity and accommodation sectors is the highest, reaching $0.84,0.83$, and 0.79 , respectively. It means that catering, commodity and accommodation have made a greatest contribution. The comprehensive direct lateral effect multiplier of the scenic area is 3.06, which shows that for each unit of value added in the scenic area, 3.06 units of value added by other relevant sectors of the national economy can be driven by the direct lateral effect. The sum of consumption in other relevant departments caused by ticket consumption through direct lateral effect is 3.06 times the consumption of scenic spots ticket consumption itself. On the whole, the direct lateral effect is significant and make great influence to the regional economy.

\section{Indirect lateral effect multiplier analysis}

As mentioned above, tourists' consumption of tickets for scenic spots will also be accompanied by consumption of related departments, and the products of related departments will consume other sectors of the national economy during the production process, which will have corresponding ripple effects. The ripple effect caused by the consumption of related departments is the indirect lateral effect caused by the consumption of scenic tickets. Therefore, the measurement of the indirect lateral effect multiplier of the scenic spot tickets is actually the measurement of the ripple effect multiplier of the relevant department consumption.

The ripple effect is a commonly used concept for researching industrial associations, and its calculation involves the concept of complete

$$
I V A_{j}=X_{j} Z_{j}=\left(x_{1}, x_{2}, \ldots, x_{n}\right)\left(z_{1}, z_{2}, \ldots, z_{n}\right)=\sum^{n} x_{i} z_{i}
$$

In order to calculate the indirect lateral effect multiplier of the relevant sector, that is, the sectors' corresponding industry ripple effect multiplier, the calculation formula is as follows:

$$
I L K_{j}=I V A_{j} \div \Delta I_{\text {ticket }}
$$

The formula for the comprehensive indirect lateral effect multiplier is as follows: consumption in input-output analysis. In the inputoutput analysis of national economic accounting, the direct consumption coefficient is represented by $a_{i j}$, which indicates the direct consumption of the product $i$ when producing one unit of product in the $\mathrm{j}$ sector, and the direct consumption coefficient matrix is represented by $A$, that is, $A=\left(a_{i j}\right)$. And the complete consumption coefficient is presented by $b_{i j}$, which means the complete consumption of the i product when producing the final product of one unit of department $j$, and the complete consumption coefficient matrix is represented by $\mathrm{B}$, that is, $\mathrm{B}=$ (bij). The relationship between the two is: $B=(I-A)^{-1}-I$, where $I$ is the identity matrix and $(\mathrm{I}-\mathrm{A})^{-1}$ is the Leontief inverse matrix.

Using the matrix of complete consumption coefficients, we could calculate the total output $\mathrm{X}$ of national economy sectors required by the increase of the direct output of each sector, which is the total consumption of the relevant sectors caused by the direct output of each sector. Calculated as follows:

$$
X_{j}=(I-A)^{-1} C
$$

Among them, $\mathrm{C}=(\mathrm{c} 1, \mathrm{c} 2, \ldots, \mathrm{cn})$ is the column vector of the intermediate input needed for the direct output of each department caused by the consumption of scenic tickets. After the total output X of each department is calculated, the value-added formula is used, that is, the formula calculates the added value generated by the consumption of the relevant departments of the scenic area through the complete consumption of the relevant departments of the national economy. 
Table-5: Indirect lateral effect multiplier caused by national natural landscape type A-class tourist attractions ticket consumption

\begin{tabular}{|l|l|l|l|l|}
\hline $\begin{array}{l}\text { Consumer } \\
\text { items }\end{array}$ & $\begin{array}{l}\text { Corresponding } \\
\text { department }\end{array}$ & $\begin{array}{l}\text { Added value of } \\
\text { total consumption }\end{array}$ & $\begin{array}{l}\text { Indirect added value caused } \\
\text { by direct output (unit: 100 } \\
\text { million /RMB) }\end{array}$ & $\begin{array}{l}\text { indirect lateral effect } \\
\text { multiplier of } \\
\text { department }\end{array}$ \\
\hline Commodity & $\begin{array}{l}\text { Tourism commodities } \\
\text { department }\end{array}$ & 111.48 & 71.82 & 0.53 \\
\hline Transportation & Road transport & 64.96 & 96.74 & 0.72 \\
\hline Catering & Catering & 113.73 & 167.17 & 1.23 \\
\hline Accommodation & Accommodation & 106.44 & 145.06 & 1.07 \\
\hline Entertainment & Entertainment & 11.62 & 9.68 & 0.07 \\
\hline Others & 5.68 & 6.72 & 0.05 \\
\hline Comprehensive indirect lateral effect multiplier & 3.67 \\
\hline
\end{tabular}

By comparing the data in Tables 4 and 5 , it can be found that the indirect lateral effect multiplier of each department caused by the consumption of tickets for natural landscape-type A scenic spots in the country is higher than its direct lateral effect multiplier, and the comprehensive indirect lateral effect multiplier is significant. The comprehensive multiplier of direct side effects also proves the comprehensiveness and comprehensiveness of the impact of the tourism industry. In the six consumption caused by the consumption of tickets for scenic spots, it can be roughly divided into three groups: the indirect lateral effect multipliers of the catering and accommodation sectors are 1.23 and 1.07 , both of which are greater than 1 , indicating the indirect lateral effect of these two sectors is significant. From the data, it can be seen that the indirect contribution of the consumption of dining and accommodation caused by the consumption of tickets in the scenic area exceeds the contribution of the consumption of scenic tickets itself. The indirect lateral effect multipliers of the department of commodity consumption and transportation consumption are 0.53 and 0.72 , respectively. The indirect lateral effects of these two sectors are also significant, indicating that the commodity sector and transportation sector caused by the consumption of scenic tickets also have a great indirect contribution to the national economy. Moreover, the proportion of the indirect lateral effect multiplier of the entertainment consumption and other consumption sectors is large. Small, 0.07 and 0.05, respectively, indicating that the entertainment and other consumption sectors caused by the consumption of tickets for scenic spots have only played a weak indirect contribution to the national economy. The calculated multiplier of the comprehensive indirect lateral effect is 3.67, which means that for each unit of added value of the natural landscape-type A-level scenic spot in the country, the indirect lateral effect can drive the added value of 3.67 units of the relevant departments of the national economy.

\section{Comprehensive lateral effect multiplier analysis}

The comprehensive lateral effect means the contribution to the national economy caused by the consumption of ticket sales in the scenic area through an exogenous path. To calculate the comprehensive lateral effect multiplier, first we need to calculate the comprehensive lateral effect multiplier of each department. The calculation formula is as follows:

$$
C L K_{j}=I L K_{j}+D L K_{j}
$$

The calculation formula for the comprehensive lateral effect multiplier is as follows:

$$
C L K=\sum_{j=1}^{n} I L K_{j}+D L K_{j} \ldots \ldots \ldots \ldots
$$

Combined formula (8) with formula (1) and formula (6), the sectoral comprehensive lateral effect multiplier of each department can be calculated, and then formula (9) can be used to calculate the comprehensive lateral effect multiplier of the scenic spot. The results of the direct, indirect and comprehensive lateral effect multipliers of related departments caused by the consumption of tickets for natural landscape-type A-level scenic spots are shown in Table 6:

Table-6: Sector direct、 indirect and comprehensive lateral effect multiplier caused by national natural landscape type A-class tourist attractions ticket consumption

\begin{tabular}{|l|l|l|l|l|}
\hline $\begin{array}{l}\text { Consumer } \\
\text { items }\end{array}$ & $\begin{array}{l}\text { Corresponding } \\
\text { department }\end{array}$ & $\begin{array}{l}\text { Direct lateral } \\
\text { effect multiplier }\end{array}$ & $\begin{array}{l}\text { Indirect lateral } \\
\text { effect multiplier }\end{array}$ & $\begin{array}{l}\text { comprehensive lateral effect } \\
\text { multipliers of each department }\end{array}$ \\
\hline Commodity & $\begin{array}{l}\text { Tourism commodities } \\
\text { department }\end{array}$ & 0.83 & 0.53 & 1.36 \\
\hline Transportation & Road transport & 0.48 & 0.72 & 1.20 \\
\hline Catering & Catering & 0.84 & 1.23 & 2.07 \\
\hline Accommodation & Accommodation & 0.79 & 1.07 & 1.86 \\
\hline Entertainment & Entertainment & 0.09 & 0.07 & 0.16 \\
\hline Others & Others & 0.04 & 0.05 & 0.09 \\
\hline Total & 3.06 & 3.67 & 6.74 \\
\hline
\end{tabular}


According to the size of the department comprehensive lateral effect multiplier, the six consumption can also be divided into three groups: the commodity and transportation sector, the catering and accommodation sector, and the entertainment and other sectors. The catering and accommodation sector is still the sector with the most significant comprehensive lateral effect. Among them, the department comprehensive lateral effect multiplier of the catering sector even reaches 2.07, and the comprehensive lateral effect multiplier of the accommodation sector is also significant, 1.86, which indicates that 1 unit the consumption of scenic tickets through the lateral effects on the catering sector and the accommodation sector can drive the added value of the national economy by 2.07 and 1.86 units, of which the growth of the national economy through the lateral effects caused by catering sector is even 2.07 times the scenic tickets consumption itself.

The department comprehensive lateral effect multipliers of the commodity and transportation sectors are 1.36 and 1.20 respectively, indicating that the consumption of 1 unit of scenic spot tickets can indirectly drive 1.36 and 1.20 unit of added value increase of the national economy through the lateral effects of commodity and transportation consumption. The comprehensive lateral effects of the entertainment and other sectors were 0.16 and 0.09 respectively, indicating that the consumption of scenic tickets for 1 unit drives the increase of the national economy by 0.16 and 0.19 units through the lateral effects on the entertainment sector and other sectors. The added value increases and the proportion is relatively small. The combined lateral effect multiplier of ticket consumption in scenic spots is 6.74 in total, which indicates that one unit added value of ticket consumption can drive the increase of 6.74 units added value in relevant economic sectors in the region through comprehensive lateral effects, indicating a significant comprehensive lateral effect.

\section{Analysis through contrast with tourism output added value multiplier}

The added value multiplier of tourism output refers to the impact of tourism consumption on the GDP of relevant local economic sectors [22]. The calculation principle is: tourism output added value multiplier $=$ the increased GDP caused by tourism consumption / GDP corresponding to tourism consumption. The tourism output value-added multiplier of scenic tickets reflects the influence of scenic ticket consumption itself on the GDP of relevant local economic departments. In calculation, the tourism output value-added multiplier of scenic tickets equals the ripple effect multiplier of scenic tickets. The calculation formula of the ripple effect multiplier has been introduced in the previous article, so it won't be repeated here. Since the consumption of scenic area tickets belongs to the public facilities management industry, the column matrix of the complete consumption coefficient of the public facilities management industry is multiplied by the added value rate of each department and then summed up. Tourism output added value multiplier is 1.44 , that is to say, the consumption of 1 unit of scenic spot tickets can only lead to the consumption of 1.44 units of the relevant national economic departments around the scenic spot through its own tourism output added value multiplier effect.The lateral effect could drive the growth of 6.74 units added value in the national economy. The multiplier effect derived from the lateral effect perspective is 4.68 times the multiplier effect of the added value of tourism output from the scenic spots. The lateral effect of landscape-type A-level scenic spots can better reflect the driving role of tourism in the surrounding economy than the multiplier of the valueadded tourism output of scenic spots.

\section{Optimization analysis of lateral effect structure of ticket consumption in scenic spots}

The added value multiplier of tourism output can reflect the industry's driving capacity in various sectors related to tourism consumption. The added value multiplier of tourism output has a greater impact on the comprehensive lateral effect multiplier of each sector, but the comprehensive lateral of each sector The effect multiplier size is not only determined by the tourism output added value multiplier, but also related to the tourist consumption structure. Comparing the corresponding tourism output added value multiplier with the comprehensive lateral effect multiplier can effectively observe the tourism consumption structure of tourists, thereby helping to scientifically choose the direction of optimizing the consumption structure of scenic spots. As mentioned above, the calculation principle of the tourism output added value multiplier is: tourism output added value multiplier = GDP corresponding to changes in total output value caused by tourism consumption / GDP corresponding to tourism consumption. Using formula (5), we can calculate the GDP corresponding to the change in gross output value caused by tourism consumption, and the GDP corresponding to tourism consumption can be obtained from Table- 3 in this paper. The calculated multiplier of tourism output value added in the scenic area and its pair with the comprehensive side effect multiplier are shown in Table-7: 
Yang Yi., Sch J Econ Bus Manag, Feb., 2020; 7(2): 55-65

Table-7: Comparing sector tourism increased output value multiplier with comprehensive lateral effect multiplier

\begin{tabular}{|l|l|l|l|}
\hline $\begin{array}{l}\text { Consumer } \\
\text { items }\end{array}$ & $\begin{array}{l}\text { Corresponding } \\
\text { department }\end{array}$ & $\begin{array}{l}\text { added value multiplier } \\
\text { of tourism output }\end{array}$ & $\begin{array}{l}\text { comprehensive lateral effect } \\
\text { multipliers of each department }\end{array}$ \\
\hline $\begin{array}{l}\text { Scenic spot } \\
\text { ticket }\end{array}$ & $\begin{array}{l}\text { Public facilities } \\
\text { management }\end{array}$ & 1.44 & 1.44 \\
\hline Commodity & $\begin{array}{l}\text { Tourism commodities } \\
\text { department }\end{array}$ & 0.64 & 1.36 \\
\hline Transportation & Road transport & 1.49 & 1.20 \\
\hline Catering & Catering & 1.47 & 2.07 \\
\hline Accommodation & Accommodation & 1.36 & 1.86 \\
\hline Entertainment & Entertainment & 0.83 & 0.16 \\
\hline Others & Others & 1.18 & 0.09 \\
\hline
\end{tabular}

It can be seen from Table-7 that the comprehensive lateral effect multiplier of each department caused by the consumption of tickets for the national A-level natural landscape scenic spots does not match the sequential output value multiplier of the corresponding tourism output, which means that the tourist attractions. The consumption structure of the destination needs to be further improved. There is still room for the industries in various sectors to play a role in driving economic growth in the national A-level scenic spots. Among the seven major consumption items, although the tourism output value-added multiplier of the corresponding department of transportation consumption reaches 1.20 , transportation consumption is rigid consumption and the potential for further development is small, so it is not the focus of side-effect structure optimization. Analyzing the other six major tourism consumption, it can be found that the tourism output value-added multipliers corresponding to scenic spot ticket consumption, catering consumption, and accommodation consumption are $1.44,1.47$, and 1.36 in order, among which the tourism output value-added multiplier for catering consumption (1.47) The largest, scenic spot tickets (1.44) ranked third, which shows that relying solely on the income of scenic spot tickets can not bring good economic income to the local area. In order to give full play to the role of tourist attractions in driving economic growth around tourist destinations, it is necessary to focus on The accommodation, catering and shopping sectors will tap into the potential of the accommodation, catering and shopping sectors and give full play to their side effects.

\section{CONCLUSIONS AND IMPLICATIONS RESEARCH CONCLUSIONS}

This study takes the national natural landscape A-level scenic area in China as an example, and uses existing data, related research methods and draw on the relevant models built by previous generations, and then comprehensively calculates the lateral effect multipliers of scenic area ticket consumption on the regional economy. The conclusions are as follows:

First, the multiplier of the added value of tourism output of natural landscape-type A-level scenic spot ticket consumption is 1.44 , that is, each additional unit of value added for scenic spot ticket consumption will drive other sectors of the national economy through its own tourism output of 1.44 Value added. And its side effect multiplier is 6.74 , that is, each additional unit of value added in the scenic spot will pull the value of 6.74 units of other sectors of the national economy through side effects. The side effect of scenic spot consumption on the regional national economy through side effects is 4.68 times its impact on the regional national economy through the tourism output value multiplier through the ticket itself.

Secondly, of the six main consumption caused by the consumption of tickets in scenic spots, the side effect multipliers of catering (2.07) consumption and accommodation (1.86) consumption are the largest group, which have a greater contribution to the tourism destination economy and transportation (1.20) and shopping (1.36) also have a greater contribution to the tourism destination economy, while entertainment (0.16) and other (0.09) side effects multipliers are smaller. Among them, catering (2.07) consumption, accommodation (1.86) consumption, transportation (1.20) consumption and shopping (1.36) consumption all contributed more to the national economy than the scenic area ticket consumption itself.

Third, the analysis of the industry driving capacity of the related departments of ticket consumption in the scenic spot can be found that the tourism output value multiplier of the catering, accommodation, shopping, and scenic areas multipliers are $1.47,1.36,0.64$, and 1.44 , respectively. The side effect multipliers are $2.07,1.86,1.36$, and 1.44 , and the side effects are much larger than the direct tourism output value-added multipliers. The tourism output value-added multiplier of scenic spot ticket consumption (1.44) ranks third among the seven major related consumptions of the scenic spot. The catering sector (1.47) and transportation sector (1.49) are both larger than the tourism output of scenic spot ticket consumption (1.44). Add value-added multipliers.

Fourth, the side effect multiplier has a direct relationship with the consumption structure. At present, the side effect multiplier of ticket consumption in scenic spots accounts for a large proportion of the side effect multiplier (1.44) of ticket consumption in the entire 
scenic spot, second only to catering consumption (2.07). And the side effect multiplier of accommodation consumption (1.86), which to a certain extent inhibited the side effects of shopping consumption, entertainment consumption and other types of tourism consumption.

\section{Research Implications}

In this paper, we calculated lateral effect multiplier for national natural landscape-type A scenic spots in China, and then conduct some analysis. The purpose of this paper is to provide a theoretical basis for the optimization of regional tourism development. Based on above research conclusions, this article draws the following management implications:

First, the natural resource-dependent scenic spots should reasonably control the ticket prices of scenic spots and improve comprehensive economic benefits. The research results in this paper show that the contribution of natural landscape-type A-level scenic spots to the regional economy through lateral effects is far greater than the tourism output added value multiplier, which means that other types of consumption driven by scenic spot ticket consumption, such as catering, accommodation, etc., contribute more to the regional economy than the scenic area ticket consumption itself. Excessive ticket prices in scenic spots are likely to curb tourists' spending on shopping, dining, and accommodation, which not only make visitors' travel experience less colorful, but also is not conducive to driving economic growth in tourist destinations.

Second, natural landscape-type scenic spots should vigorously support the development of local specialty accommodation, gourmet cuisine, and specialty shopping, and actively enhance the lateral effects of scenic spot consumption. Although tourism transportation consumption is rigid consumption, there is little potential for further promotion, but accommodation, catering, shopping, etc. are flexible consumption and have great potential for promotion. Special accommodation, specialty food and specialty shopping can not only provide tourists with a wealth of product choices and enhance the attraction of the scenic spot, but also drive local employment and drive the surrounding area economy through lateral effects. Many natural landscape-type scenic spots have local special agricultural products, agricultural and sideline products, which can be further developed into tourist commodities and tourist souvenirs, providing tourists with a characteristic tourism shopping experience, and giving full play to the role of natural scenic spots in driving the surrounding economy.

\section{REFERENCES}

1. Liu Yi, Zhang Meng Fan. A Study on Comprehensive Multiplier Effect upon Regional Economy and Diffusion Paths Caused by Consumption of the World Natural Heritage
Scenic Spot $[\mathrm{J}]$ Industrial Economic Review, 2017; 8(4):110-122.

2. Chen Xiaozhen, Zhao Bing Xin, Xiao Wenwen. Research on the Industrial Side Network [J]. Chinese Journal of Management Science, 2014; 22(11):122-130.

3. Archer B. Importance of Tourism for the Economy of Bermuda [J]. Annals of Tourism Research, 1995, 22(4):918-930.

4. Archer B, Fletcher J. The Economic Impact of Tourism in the Seychelles [J]. Annals of Tourism Research, 1996; 23(1):32-47.

5. Sun YY. Adjusting Input-output Models for Capacity Utilization in Service Industries [J]. Tourism Management, 2007; 28(6):1507-1517.

6. Romero I, Tejada PA. Multi-level Approach to the Study of Production Chains in the Tourism Sector [J]. Tourism Management, 2011; 32(2):297-306.

7. Yee-Lee C, Eng-Heng L, Dao-Siang JM, Ai-Na S, Siu-Eng T, Boon-Hui BC. Indirect Economic Effect of Tourist Spending On the Tourism Industry in Penang-A Justification of the PostPositivism Approach. International Journal of Academic Research. 2013 Jan 1;5(1).

8. Dwyer L, Forsyth P, Spurr R. Evaluating Tourism's Economic Effects: New and Old Approaches [J]. Tourism Management, 2004; 25(3): 307-317.

9. Pratt S. Economic Linkages and Impacts across the TALC [J]. Annals of Tourism Research, 2011, 38(2):630-650.

10. Meng X, Siriwardana M, Pham T. A CGE Assessment of Singapore's Tourism Policies [J]. Tourism Management, 2013; 34: 25-36.

11. Pratt $\mathrm{S}$. The Economic Impact of Tourism in SIDS [J]. Annals of Tourism Research, 2015;52:148-160.

12. Robertico C, Manuel AR. Tourism's potential to benefitthe poor: A social accountingmatrix model appliedto Ecuador [J]. Tourism Economics, 2017; 23(1):29-48

13. Zhang Wenjian, Kan Yanlei. An analysis on correlation and spread of tourism industry in Shanghai [J]. Journal of Social Sciences, 2003(8):21-27.

14. Li Weike, Liu Jinping, Guo Yue. An Analysis of Enterprise Spread in Chongqing Tourist Industry on the Base of Input-output Analysis [J]. Journal of Nanjing Xiaozhuang University, 2006; (4):96100.

15. Qiao Wei. Study of the Tour Industry Spatial Layout of the Yangtze River Delta [J]. Economic Geography, 2006(S2):63-66+86.

16. Song Zengwen. A Research on Industrial Correlation of China's Tourism Industry : Based on the Input-output Model+Tourism Science [J]. Tourism Science, 2007, (2):7-12, 78.

17. Wang Yan, Wang Zhe. An Analysis on Industrial Correlation and spread of Xinjiang's Tourism 
Industry: Based on the Input-output Model [J]. Journalof Arid Land Resources and Environment, 2008, (5):112-117.

18. Li Jie, Lian Chuanpeng. A Comparative Study on Jiangsu tourism multiplier in 2002 Based on the Input-output Table and Social Accounting Matrix [J]. Tourism Tribune, 2009, 24(03):30-35.

19. Cui Feng, Bao Juan. An Analysis of Tourism Industrial Correlation and Industrial Spread Effecting Zhejiang Province [J]. Tourism Tribune, 2010; (3):13-20.

20. Liu Xiaoxin, HuXiao, Zhou Hong. An Analysis of the Measurement of Correlation of China's Tourism Industry and Macro economic Effects: Based on the Perspective of Input-output [J]. Tourism Tribune, 2011; (3):31-37.

21. Liu Qiyun. Correctly understand and use inputoutput multipliers [J]. Journal of Renmin University of China, 2003,17(6):89-95.

22. Li Yinlan. Discussion on the Measurement Method of Tourism Output Added Value Multiplier Effect [J]. Statistics and Decision, 2004(3):10-11. 